\title{
Autotrophic component of soil respiration is repressed by drought more than the heterotrophic one in dry grasslands
}

\author{
János Balogh ${ }^{1}$, Marianna Papp ${ }^{2}$, Krisztina Pintér ${ }^{2}$, Szilvia Fóti ${ }^{2}$, Katalin Posta ${ }^{3}$, Werner Eugster ${ }^{4}$, and Zoltán Nagy ${ }^{1,2}$ \\ ${ }^{1}$ Institute of Botany and Ecophysiology, Szent István University, Gödöllő, Hungary \\ ${ }^{2}$ MTA-SZIE Plant Ecology Research Group, Szent István University, Gödöllő, Hungary \\ ${ }^{3}$ Institute of Plant Protection, Szent István University, Gödöllő, Hungary \\ ${ }^{4}$ Grassland Sciences Group, Institute of Agricultural Sciences, ETH Zurich, Zurich, Switzerland
}

Correspondence to: János Balogh (balogh.janos@mkk.szie.hu)

Received: 13 August 2015 - Published in Biogeosciences Discuss.: 20 October 2015

Revised: 12 August 2016 - Accepted: 2 September 2016 - Published: 19 September 2016

\begin{abstract}
Summer droughts projected to increase in central Europe due to climate changes strongly influence the carbon cycle of ecosystems. Persistent respiration activities during drought periods are responsible for a significant carbon loss, which may turn the ecosystem from a sink into a source of carbon. There are still gaps in our knowledge regarding the characteristic changes taking place in the respiration of the different components of the ecosystem in response to drought events.

In the present study, we combined a physical separation of soil respiration components with continuous measurements of soil $\mathrm{CO}_{2}$ efflux and its isotopic $\left({ }^{13} \mathrm{C}\right)$ signals at a dry grassland site in Hungary. The physical separation of soil respiration components was performed by means of inox meshes and tubes inserted into the soil. The root-excluded and rootand mycorrhiza-excluded treatments served to measure the isotopic signals of the rhizospheric, mycorrhizal fungi and heterotrophic components, respectively.

In the dry grassland investigated in the study the three components of the soil $\mathrm{CO}_{2}$ efflux decreased at different rates under drought conditions. During drought the contribution made by the heterotrophic components was the highest (54 $\pm 8 \%$; mean $\pm \mathrm{SE})$. Rhizospheric component was the most sensitive to soil drying with its relative contribution to the total soil respiration dropping from $66 \pm 7$ (non-stressed) to $35 \pm 17 \%$ (mean $\pm \mathrm{SE}$ ) under drought conditions. According to our results the heterotrophic component of soil respiration is the major contributor to the respiration activities during drought events in the dry grassland ecosystem studied.
\end{abstract}

\section{Introduction}

Grassland ecosystems respond forcefully to drought events via substantial reduction of their primary production (GPP; Hoover et al., 2014; Parton et al., 2012; Reichstein et al., 2013). In contrast, belowground respiration is not so strongly affected (van der Molen et al., 2011; Yang and Zhou, 2013) but tends to be reduced as well under drought (Balogh et al., 2011; Suseela and Dukes, 2013). Soil respiration is the second largest component of carbon cycling in grasslands and returns as much as $50-90 \%$ of annual GPP back to the atmosphere (Bahn et al., 2008). Thus, the magnitude of soil respiration can turn the carbon budget from a net sink into a net source in dry years (Nagy et al., 2007). Here we address the question whether under drought this is primarily a function of autotrophic respiration declining along with the soil drying while heterotrophic respiration remains less affected.

According to climate change scenarios the frequency of droughts is expected to increase in central Europe (Prudhomme et al., 2014), where dry grassland ecosystems represent one of the major land use types. It is well known that there is a need for better mechanistic models to address the effects of climatic extremes on carbon fluxes (e.g., Blagodatsky and Smith, 2012). However, progress has so far been limited due to the high complexity of responses given by the different ecosystem respiration components to the climatic drivers.

Soil organic matter (SOM) and litter-derived respiration is considered to belong to the heterotrophic soil respiration component (Moyano et al., 2009). Their decomposition is at- 
Table 1. Measured and estimated $\mathrm{CO}_{2}$ effluxes and isotopic signals in this study.

\begin{tabular}{lll}
\hline & $\mathrm{CO}_{2}$ efflux & Isotopic signals \\
\hline Measured & $R_{\text {eco }}, R_{\text {soil }}, R_{\text {re }}, R_{\text {rme }}$ & $\delta^{13} \mathrm{C}_{R_{\text {eco }}}, \delta^{13} \mathrm{C}_{R_{\text {soil }},}, \delta^{13} \mathrm{C}_{R_{\text {re }}}, \delta{ }^{13} \mathrm{C}_{R_{\text {rme }}}$ \\
Estimated & $R_{\text {rhizo }}, R_{\text {myc }}, R_{\text {het }}$ & $\delta^{13} \mathrm{C}_{R_{\text {mycrhiz }}} \delta^{13} \mathrm{C}_{R_{\text {rhizo }},}, \delta^{13} \mathrm{C}_{R_{\text {myc }}}$ \\
\hline
\end{tabular}

tributed mainly to soil bacteria and fungi and has about $50 \%$ share in the total soil respiration in dry grasslands (Bao et al., 2010; Chen et al., 2009; Gomez-Casanovas et al., 2012). In contrast, some of the soil fungi relying on recent photosynthetic assimilates contribute to the autotrophic respiration component. Arbuscular mycorrhizal fungi (AMF) are obligatory symbiont soil fungi, forming intimate mutualistic associations in $70-90 \%$ of the plant species in grasslands (Hiiesalu et al., 2014). About 10-20\% of the assimilated C may be attributed to AMF in exchange for acquiring water and essential nutrients for plant productivity (van der Heijden et al., 2015). Therefore soil respiration includes components of an autotrophic-heterotrophic continuum from roots through the root-associated fungi (rhizospheric and mycorrhizal) to non-root-associated (heterotrophic) microbial components.

Belowground $\mathrm{CO}_{2}$ production by the autotrophic and heterotrophic components show large diel and seasonal variability (Fassbinder et al., 2011; Moyes et al., 2010). The drivers behind all this are not fully revealed and the role of soil microbes in the process is still not clear mainly due to the diversity of soil biota (Bardgett et al., 2008). Moreover, drivers of $\mathrm{CO}_{2}$ production frequently interact with each other (Balogh et al., 2015; Vargas et al., 2010), hampering the partitioning of the total $\mathrm{CO}_{2}$ efflux into components. Studies found a stronger effect of photosynthesis than that of temperature on root respiration (Gomez-Casanovas et al., 2012; Heinemeyer et al., 2012; Hopkins et al., 2013). Both autotrophic and heterotrophic components were shown to be sensitive to water shortages (Carbone et al., 2011; Moyano et al., 2013). The autotrophic component was found to be dominant over the heterotrophic one during drought periods in a Mediterranean woodland ecosystem (Casals et al., 2011), but we have limited information about grasslands of shallow rooted herb species regarding the dominant source of carbon during drought periods.

The widely used separation techniques (trenching and girdling) are not considered suitable for grasslands (Epron, 2009); thus the physical separation of the soil $\mathrm{CO}_{2}$ efflux components via root exclusion is hardly feasible without seriously disturbing the soil structure and the root system. A viable option, however, is the use of stable isotopic signatures $\left(\delta^{13} \mathrm{C}\right)$ of soil respiration to estimate the relative contributions of the main components (Carbone et al., 2011; Hopkins et al., 2013). Although diel patterns in $\delta^{13} \mathrm{C}$ may also be subject to biases in the measuring methods (Fassbinder et al., 2011; Midwood and Millard, 2011), seasonal changes are expected to reflect the changes in the contribu- tions of source components rather than the changes in the isotopic signals of the component itself (Knohl et al., 2005). However, SOM $\delta^{13} \mathrm{C}$ can also change during the year with fresh plant material being more depleted in ${ }^{13} \mathrm{C}$ than the older SOM components (Bowling et al., 2002); therefore fresh litter may contribute to the decreasing $\delta^{13} \mathrm{C}$ of the heterotrophic component. Drying of the surface layers can also modify ${ }^{13} \mathrm{CO}_{2}$ since heterotrophic respiration could be restricted to the deeper layers of the soil (Moyes et al., 2010). Drying of the soil can also change the amount of $\mathrm{CO}_{2}$ produced in the topsoil layer (Balogh et al., 2015) by allowing greater atmospheric invasion and thereby enriching soil air in ${ }^{13} \mathrm{C}$ (Phillips and Nickerson, 2010). The disequilibrium between the measured isotopic composition and the isotopic composition of the respiratory source could be significant especially in tracer experiments (Gamnitzer et al., 2011) but it is assumed to be less pronounced in open-chamber measurements due to the steady-state diffusion (Nickerson et al., 2013).

Uncertainties in estimating the contributions of soil respiration components could be reduced by a combination of different methodologies (Risk et al., 2012). The question we are asking is, which of the investigated soil respiration components (autotrophic - including rhizospheric and mycorrhizal fungi - and heterotrophic components) of the dry grasslands dominates during drought? Our hypothesis was that autotrophic respiration would be reduced linearly with photosynthesis, whereas heterotrophic respiration might not be affected as strongly, resulting in a net loss of $\mathrm{C}$ from the soil carbon reservoir. In order to achieve our goals we used an experimental approach based on the physical separation of soil respiration components combined with measurements of soil $\mathrm{CO}_{2}$ efflux and its isotopic $\left({ }^{13} \mathrm{C}\right)$ signal.

\section{Methods}

\subsection{Site description}

The vegetation at the Bugac site $\left(46.69^{\circ} \mathrm{N}, 19.6^{\circ} \mathrm{E}\right.$; $114 \mathrm{~m}$ above sea level) is a dry sandy grassland dominated by Festuca pseudovina, Carex stenophylla and Cynodon dactylon and it was under extensive grazing for 20 years prior to our study. Ten-year mean annual precipitation (20042013) was $575 \mathrm{~mm}$ and the mean annual temperature reached $10.4^{\circ} \mathrm{C}$. The soil is a chernozem-type sandy soil with high organic carbon content (Balogh et al., 2015).

\subsection{Spatial separation of soil $\mathrm{CO}_{2}$ efflux components}

In 201010 soil cores $(160 \mathrm{~mm}$ in diameter and $800 \mathrm{~mm}$ in depth, one of them $600 \mathrm{~mm}$ in diameter) were excavated. The roots were removed and the root-free soil was packed back - layer by layer - into PVC tubes with the same dimensions. Four tubes were used to exclude both roots and mycorrhiza. Walls of another six tubes were partially removed and replaced by inox mesh $(40 \mu \mathrm{m}$ mesh size) to exclude roots 
while ensuring that the mycorrhiza filaments can grow into the tubes (Moyano et al., 2007). These root-free and rootand mycorrhiza-free soil cores were settled at a distance of $6 \mathrm{~m}$ from the eddy covariance (EC) tower to the south direction (Supplement Fig. S1). The distance between the soil cores $/$ tubes was $50 \mathrm{~cm}$.

Soil $\mathrm{CO}_{2}$ efflux and its isotopic signal were measured in plots:

- with undisturbed soil (various positions, 36 positions in total within a $\sim 4 \mathrm{~m}^{2}$ plot): total soil respiration, $R_{\text {soil }}$, $\delta^{13} \mathrm{C}_{R_{\text {soil }}}$;

- without roots and AMF (four spatial replications): heterotrophic component only, $R_{\mathrm{rme}}, \delta^{13} \mathrm{C}_{R_{\mathrm{rme}}}$;

- with root-excluded soil (six spatial replications): without roots, but with AMF, $R_{\mathrm{re}}, \delta^{13} \mathrm{C}_{R_{\mathrm{re}}}$.

\subsection{Gas exchange measuring systems}

Three different gas exchange systems were used in our study: EC system, automated soil respiration measuring system (SRS) connected to an isotopic $\mathrm{CO}_{2}$ analyzer (cavity ringdown spectroscopy system, CRDS). The experimental area was in the EC footprint (Fig. S1) but the size of the EC flux footprint area was larger by several orders of magnitude than the area covered by the SRS. Care was taken during the establishment of the experiment to select a plot with the same average soil characteristics and vegetation cover as found in the EC footprint area. Hence, the net ecosystem exchange (NEE) and evapotranspiration (ET) estimates obtained in this way can be considered representative also for the small-scale SRS and isotope measurements.

Data from 15 May to 12 November 2013 (182 days) were analyzed in the present study.

\subsubsection{Eddy covariance setup}

The EC system at the Bugac site measured the $\mathrm{CO}_{2}$ and $\mathrm{H}_{2} \mathrm{O}$ fluxes continuously from 2002. In dry years the grassland can turn into a net carbon source (Nagy et al., 2007) but the longer-term annual sums of NEE showed it to be a net sink, ranging from -171 to $+106 \mathrm{~g} \mathrm{C} \mathrm{m}^{-2} \mathrm{yr}^{-1}$ (Pintér et al., 2010) with a $-100 \mathrm{~g} \mathrm{C} \mathrm{m}^{-2} \mathrm{yr}^{-1}$ average.

The EC system consists of a CSAT3 sonic anemometer (Campbell Scientific, USA) and a Li-7500 (Licor Inc, USA) open-path infrared gas analyzer (IRGA), both connected to a CR5000 data logger (Campbell Scientific, USA) via an SDM (synchronous device for measurement) interface. Additional measurements used in this study were air temperature and relative humidity (HMP35AC; Vaisala, Finland), precipitation (ARG 100 rain gauge; Campbell, UK), global radiation (dual pyranometer; Schenk, Austria), incoming and reflected photosynthetically active radiation (SKP215; Campbell, UK), volumetric soil moisture content (CS616; Campbell, UK) and soil temperature (105T; Campbell, UK). These measurements were performed as described by Nagy et al. (2007) and Pintér et al. (2010). Fluxes of sensible and latent heat and $\mathrm{CO}_{2}$ were processed using an IDL program after Barcza et al. (2003) adopting the CarboEurope IP methodology. For a detailed description of data processing and gapfilling see Nagy et al. (2007) and Farkas et al. (2011).

\subsubsection{Soil respiration system}

The 10-chamber automated soil respiration system was set up in July 2011. The system is an open dynamic one, consisting of an SBA-4 infrared gas analyzer (PPSystems, UK), pumps, flow meters (D6F-01A1-110, Omron Co., Japan), electromagnetic valves and PVC/metal soil chambers (Fig. S3). The chambers were $10.4 \mathrm{~cm}$ high with a diameter of $5 \mathrm{~cm}$, covering a soil surface area of $19.6 \mathrm{~cm}^{2}$. The flow rate through the chambers was $300 \mathrm{~mL} \mathrm{~min}^{-1}$, replacing the air in the chamber in $40 \mathrm{~s}$. The PVC chambers were enclosed in a white metal cylinder with $2 \mathrm{~mm}$ airspace in between to stabilize the chamber and to prevent warming by direct radiation. Four vent holes with a total area of $0.95 \mathrm{~cm}^{2}$ were drilled on the top of the chambers. Vent holes also served to allow precipitation to drip into the chambers. Chamber walls exceeded the chamber top by $3 \mathrm{~mm}$ directing precipitation to the vent holes. The system caused minor disturbances in the soil structure and the spatial structure of the vegetation. It was applied without cutting the leaves/shoots of the plants, so it did not disturb transport processes taking place inside the plant stems and roots. It was suitable for continuous, long-term unattended measurements of soil $\mathrm{CO}_{2}$ efflux and was also used in previous experiments (Balogh et al., 2015; Nagy et al., 2011). The soil respiration chambers contained no standing aboveground plant material. Before the study the system was tested on a calibration tank (CzechGlobe, Brno, Czech Republic) against known fluxes $\left(F_{\mathrm{SRS}}=0.98 \times F_{\text {calibration_tank }}\right.$, $R^{2}=0.92, n=86$ ) and it was also compared to a LI-6400 system at the study site $\left(F_{\mathrm{SRS}}=0.92 \times F_{\mathrm{LI} 6400}, R^{2}=0.92\right.$, $n=36$ ).

Other studies (Nickerson et al., 2013; Risk et al., 2011) also used this chamber size, arguing that these chambers could be placed between the plants in grasslands, while larger chambers might create a non-representative surface due to the cutting necessary for placing the chambers on the ground (Risk et al., 2011).

$R_{\text {soil }}$ was measured by six SRS chambers, while $R_{\text {rme }}$ and $R_{\text {re }}$ were measured by two SRS chambers, respectively.

\subsubsection{Isotopic $\left({ }^{13} \mathrm{CO}_{2}\right)$ measurements}

A Picarro G1101-i gas analyzer (CRDS; Picarro Inc., CA, USA) was attached to the soil respiration system from May to November 2013. This CRDS system measured the isotopic composition inside the chambers and in the reference air. Reference air was sampled $10 \mathrm{~cm}$ above the surface in 
the foliage of plants. The SRS sequentially measured each of the 10 chambers for $3 \mathrm{~min}$. Every second chamber was additionally probed for isotopic signature measurements by the CRDS ( $3 \mathrm{~min}$ ), followed by reference air measurements for another $3 \mathrm{~min}$. Thus, the isotopic measurements of five chambers took $30 \mathrm{~min}$ in a single cycle. The CRDS integration time was set at $10 \mathrm{~s}$, and thus the CRDS provided 18 measurement points per chamber per cycle. Although the system response of the CRDS was clearly slower than the response of the SRS, the 3 min duration was long enough to obtain robust results. Since CRDS followed the 3 min intervals of SRS measurements no additional grace time had to be considered for the isotopic measurements.

Although this sampling scheme provides very good temporal coverage (replication in time), it is not perfectly addressing spatial variability and hence the position of each of the chambers was moved 11 times to randomly selected locations during the study period (i.e., every $2-3$ weeks) to obtain sequential spatial replications for each plot type (undisturbed, root-excluded, root- and mycorrhizal-fungiexcluded; see Figs. S1 and S2). More precisely, $\delta^{13} \mathrm{C}_{R_{\text {soil }}}$ was measured by three chambers at 36 (three chambers $\times 12$ positions) randomly selected positions within the experimental area (undisturbed soil, Fig. S1). $\delta^{13} \mathrm{C}_{R_{\mathrm{re}}}$ was measured by one chamber which was moved to positions $1,3,5,6,8$ and 9 during the study period (Fig. S2). $\delta^{13} \mathrm{C}_{R_{\mathrm{rme}}}$ was measured by one chamber which was moved to positions $2,4,7$ and 10 during the study period (Fig. S2).

Since contributions by the different soil $\mathrm{CO}_{2}$ efflux components were estimated for five different periods within the study period distinguished by NEE, soil water content (SWC) values and isotopic signals (see Results), data for each estimation originated from two to three spatial replications.

\subsection{Data processing and modeling}

Data processing and statistical analysis were done in $R(R$ Core Team, 2014). Before calculating daily averages of $\delta^{13} \mathrm{C}$ values a filtering method was applied to each dataset. Out of each 180 -second-long measurement on a certain chamber, the first $70 \mathrm{~s}$ (to measure a steady-state signal) and the last $20 \mathrm{~s}$ were cut and the remaining values were used for further calculations. As reference and chamber air were measured, sequentially reference values during chamber measurements were estimated by linear interpolation between the neighboring reference sequences.

After the interpolation, $\delta^{13} \mathrm{C}$ values of the soil $\mathrm{CO}_{2}$ efflux were calculated using the isotopic mass balance approach in each plot:

$\delta^{13} \mathrm{C}_{R}=\frac{\delta^{13} \mathrm{C}_{\text {out }} \times c_{\text {out }}-\delta^{13} \mathrm{C}_{\mathrm{in}} \times c_{\text {in }}}{c_{\text {out }}-c_{\text {in }}}$,

where $\delta^{13} \mathrm{C}_{\text {out }}$ and $\delta^{13} \mathrm{C}_{\text {in }}$ are the isotopic signature of the outgoing and incoming air of the chamber and $c_{\text {out }}$ and $c_{\text {in }}$ are the $\mathrm{CO}_{2}$ concentrations of the outgoing and incoming air of the chamber, respectively.

$\delta^{13} \mathrm{C}=\frac{R_{\text {sample }}}{R_{\text {standard }}}-1$,

where $R$ stands for the ${ }^{13} \mathrm{C}:{ }^{12} \mathrm{C}$ isotope ratio of the sample and the international VPDB standard (0.011182), respectively.

Individual measurements were filtered out by using a moving-window procedure if the investigated value (at the window center) was outside the range of the mean \pm median absolute deviation of the values in a 10-day moving window. This filtering procedure left an overall data availability of $68-70 \%$. Daily averages were calculated using the remaining data.

To determine the isotopic signature of the ecosystem respiration $\left(R_{\text {eco }}\right)$, Keeling plots were constructed by plotting the nighttime $\delta^{13} \mathrm{C}$ values measured $10 \mathrm{~cm}$ over the surface against the inverse of the $\mathrm{CO}_{2}$ concentration. The extrapolated $y$ intercept of the linear regression was used as $\delta^{13} C_{R_{\text {eco }}}$ values.

Total soil $\mathrm{CO}_{2}$ efflux was separated isotopically into its components. We defined the components following the terminology presented by Moyano et al. (2009):

- Heterotrophic respiration is microbial respiration from litter and SOM decomposition.

- Autotrophic respiration is mycorrhizospheric respiration including rhizospheric and mycorrhizal fungi components.

- Rhizospheric respiration is respiration of roots and rootassociated microorganisms in the rhizosphere, not including mycorrhizal fungi.

Two-source mixing models were used to estimate the fraction $(a)$ of the rhizospheric and $(b)$ mycorrhizospheric components based on the measured isotopic signals:

$\delta^{13} \mathrm{C}_{R_{\text {soil }}}=a \times \delta^{13} \mathrm{C}_{R_{\text {rhizo }}}+(1-a) \times \delta^{13} \mathrm{C}_{R_{\mathrm{re}}}$,

$\delta^{13} \mathrm{C}_{R_{\text {soil }}}=b \times \delta^{13} \mathrm{C}_{R_{\text {mycrhiz }}}+(1-b) \times \delta^{13} \mathrm{C}_{R_{\text {rme }}}$,

where $\delta^{13} \mathrm{C}_{R_{\text {soil }}}$ is the $\delta^{13} \mathrm{C}$ of the total soil $\mathrm{CO}_{2}$ efflux, $\delta^{13} \mathrm{C}_{R_{\mathrm{re}}}$ is the $\delta^{13} \mathrm{C}$ of the root-excluded soil, $\delta^{13} \mathrm{C}_{R_{\mathrm{rme}}}$ is the $\delta^{13} \mathrm{C}$ of the root- and mycorrhiza-excluded soil (heterotrophic respiration), $a$ is the fraction of the rhizospheric component $\left(R_{\text {rhizo }}\right)$ and $b$ is the fraction of the mycorrhizospheric component $\left(R_{\text {mycrhiz }}\right)$ to the total soil efflux. According to these equations $1-b$ represents the ratio of heterotrophic respiration component to the total soil efflux and $b-a$ represents the ratio of mycorrhizal fungi component.

$\delta^{13} \mathrm{C}_{R_{\mathrm{rhizo}}}$ value was estimated by plotting $\delta^{13} \mathrm{C}_{R_{\text {soil }}}$ values against the $R_{\text {re }} / R_{\text {soil }}$ ratio (Fig. S3b). Since $R_{\text {re }} / R_{\text {soil }}$ is hypothetically zero when only rhizospheric respiration is present, $y$ intercept of the linear regression was assumed 
as $\delta^{13} \mathrm{C}_{R_{\text {rhizo }}} \cdot \delta^{13} \mathrm{C}_{R_{\text {mychiz }}}$ was estimated using the same approach (Fig. S3a), $\delta^{13} \mathrm{C}_{R_{\text {soil }}}$ values were plotted against the $R_{\text {rme }} / R_{\text {soil }}$ ratio and $y$ intercept of the linear regression was

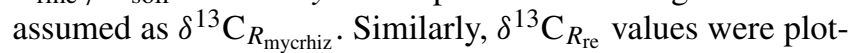
ted against the $R_{\mathrm{rme}} / R_{\mathrm{re}}$ ratio and $y$ intercept of the linear regression was assumed as $\delta^{13} \mathrm{C}_{R_{\text {myc }}}$ (Fig. S4c) but this value was not used in further calculations.

Contributions of rhizospheric, mycorrhizal fungi and heterotrophic respirations to total soil respiration were calculated by the mixing models applied on subsets (periods) of the dataset of the total study period. Estimated values of rhizospheric $\left(R_{\text {rhizo }}\right)$, mycorrhizal fungi $\left(R_{\text {myc }}\right)$ and heterotrophic respiration $\left(R_{\text {het }}\right)$ were calculated by multiplying the measured $R_{\text {soil }}$ rates (total soil respiration) with the estimated fractional contributions $(F)$ of each component as follows:

$$
\begin{aligned}
R_{\text {het }} & =R_{\text {soil }} \times F_{\text {het }}, \\
R_{\text {rhizo }} & =R_{\text {soil }} \times F_{\text {rhizo }}, \\
R_{\text {myc }} & =R_{\text {soil }} \times F_{\text {myc }},
\end{aligned}
$$

where $F_{\text {het }}, F_{\text {rhizo }}$ and $F_{\text {myc }}$ are the fractions of the heterotrophic, rhizospheric and mycorrhizal respiration in total soil respiration, respectively.

\subsection{Microbial investigations}

Soil samples for the microbial investigations were taken after the gas exchange measurements in May 2014 to avoid the disturbance of the measurements by sampling the soil. Sampling date was chosen considering the maximum of the carbon sequestration capacity of the investigated grassland (Nagy et al., 2007). Soil samples were taken from five soil layers $(0-10,10-20,20-30,30-40$ and $40-50 \mathrm{~cm})$ in each plot.

Determination of AM fungal hyphal length in the soil was based on the methods of Bååth and Söderström (1979) using separation by wet sieving and centrifugation. The separated fungal hyphae were stained using agar solution $(0.75 \%)$ containing trypan blue $(0.05 \%)$, then dried for $24 \mathrm{~h}$ at $70^{\circ} \mathrm{C}$. The hyphal length was measured in the dried agar film by the intersection method (Tennant, 1975) under a binocular microscope.

The fluorescein diacetate (FDA) hydrolysis assay was used to estimate the total microbial activity in soil samples and expressed as mg fluorescein-released $\mathrm{kg}^{-1}$ dry soil (Adam and Duncan, 2001).

\subsection{Uncertainty assessment}

Isotopic signals of soil-respired $\mathrm{CO}_{2}$ were studied extensively but several uncertainties related to the different methods were also revealed. Steady-state methods were found to provide more robust estimates than static chambers but still charged with biases (e.g., diffusive fractionation; Nickerson and Risk, 2009). Open systems have the advantage of unattended automatic measurement collecting large amount of data but are less sensitive to small isotopic differences (Midwood and Millard, 2011).

In our study $\delta^{13} \mathrm{C}_{R_{\text {eco }}}$ estimates were independent of chamber-related biases, using nighttime $\delta^{13} \mathrm{CO}_{2}$ and $\mathrm{CO}_{2}$ concentration data of the free air over the surface for the calculation (Keeling plot approach). This approach gave similar results to the chamber-based measurements, providing also partial verification of the latter ones. Moreover, isotopic measurements were independent of soil $\mathrm{CO}_{2}$ efflux measurements, since IRGA and CRDS systems took different air samples from the same soil chambers. Isotopic data together with $\mathrm{CO}_{2}$ efflux rates were collected during 1980 measurement cycles on 182 days in order to have robust estimates of isotopic signals.

A C4 grass (Cynodon dactylon) was also present in the study site potentially modifying the $\delta^{13} \mathrm{C}$ of the respired $\mathrm{CO}_{2}$. Its cover was about $10 \%$ in the pasture (Koncz et al., 2014) but it was less frequent (i.e., less than $5 \%$ ) in the experimental area. Calculated uncertainties of the relative contributions of each components (rhizospheric, mycorrhizal fungi and heterotrophic) contain the uncertainty due to a possible $5 \%$ contribution by the $\mathrm{C} 4$ grass. The isotopic signal of $\mathrm{CO}_{2}$ efflux by the $\mathrm{C} 4$ plant was supposed to be $-14 \%$.

In order to estimate the uncertainty of the measurements and estimated contributions by the different components to the total soil respiration random errors of each factor $\left(\mathrm{CO}_{2}\right.$ concentrations, isotopic compositions, model fit errors and possible $\mathrm{C} 4$ contribution) were propagated by Gaussian error propagation (Lo, 2005).

\section{Results}

\subsection{Meteorological conditions, NEE, ET, soil $\mathrm{CO}_{2}$ efflux and $\delta^{13} \mathrm{C}$ of $\mathrm{CO}_{2}$ efflux}

The end of May to the beginning of June was the most productive period in the year due to ample water availability with the lowest NEE (strongest carbon sink activity) and highest ET values being measured in this period (Fig. 1a). It rained only a few times from the end of June to $19 \mathrm{Au}-$ gust (total precipitation: $10 \mathrm{~mm}$ ) and the accompanying high temperature resulted in drought. Daily minimum NEE was around zero at the end of July and in August. Rain events after the drought period had significant effects on soil $\mathrm{CO}_{2}$ effluxes (Fig. 1c). There was a second active period following autumn rains but $\mathrm{CO}_{2}$ uptake and ET were smaller than in May or June.

$R_{\text {soil }}$ was the highest among the soil $\mathrm{CO}_{2}$ effluxes, while $R_{\text {rme }}$ was the lowest; the average $\mathrm{CO}_{2}$ effluxes in the whole study period were $5.0 \pm 2.1,3.8 \pm 1.6$ and $2.6 \pm 1.2 \mu \mathrm{mol} \mathrm{CO} \mathrm{Cm}^{-2} \mathrm{~s}^{-1}$ (mean $\pm \mathrm{SD}$ ) in $R_{\text {soil }}, R_{\mathrm{re}}$ and $R_{\text {rme }}$, respectively (Table 2 ). $R_{\text {re }}$ was sometimes higher 


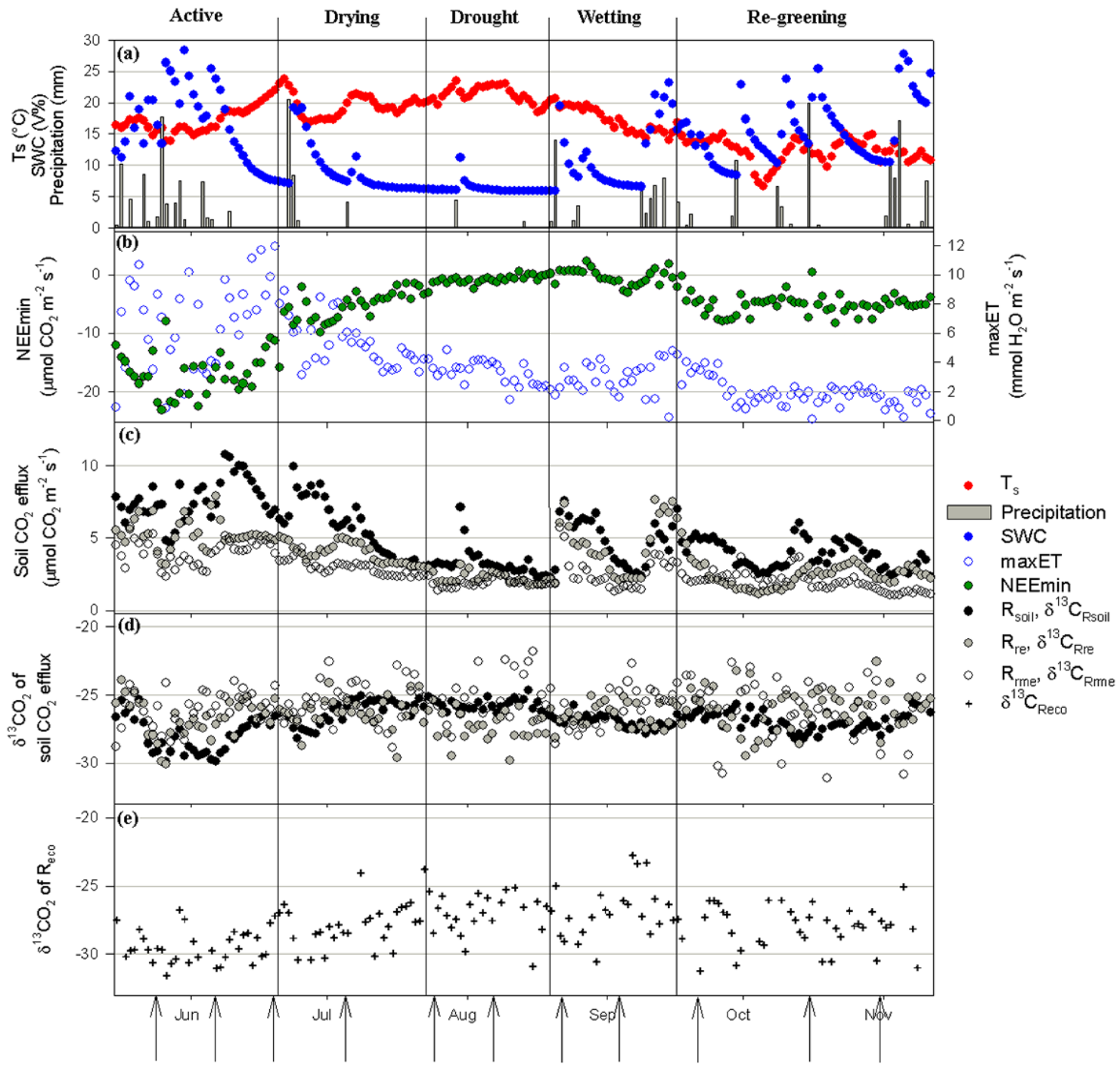

Figure 1. (a) Daily averages of soil temperature $\left(T_{\mathrm{S}}\right)$, soil water content $(\mathrm{SWC})$ at $5 \mathrm{~cm}$ depth and daily sum of precipitation; (b) daily minimum half-hourly NEE (NEEmin) and maximum half-hourly ET (maxET); (c) daily averages of $\mathrm{CO}_{2}$ efflux in undisturbed soil $\left(R_{\text {soil }}\right)$, root-excluded soil $\left(R_{\mathrm{re}}\right)$ and root- and mycorrhizal-fungi-excluded soil $\left(R_{\mathrm{rme}}\right)$; (d) daily averages of $\delta^{13} \mathrm{C}$ of soil CO $\mathrm{CO}_{2}$ efflux in undisturbed soil $\left(\delta^{13} \mathrm{C}_{R_{\text {soil }}}\right)$, root-excluded soil $\left(\delta^{13} \mathrm{C}_{R_{\mathrm{re}}}\right)$ and root- and mycorrhizal-fungi-excluded soil $\left(\delta^{13} \mathrm{C}_{R_{\mathrm{rme}}}\right)$; and (e) daily averages of $\delta^{13} \mathrm{C}$ of ecosystem respiration $\left(\delta^{13} \mathrm{C}_{R_{\text {eco }}}\right.$ ) during the study period in 2013, at Bugac site. Arrows indicate the positions changes of the soil chambers. Gray horizontal lines show $y$ major values.

Table 2. Mean measured (undisturbed soil and tubes) and estimated (heterotrophic, mycorrhizal fungi and rhizospheric) respiration rates for the different periods $\left(\mu \mathrm{mol} \mathrm{CO} \mathrm{CO}^{-2} \mathrm{~s}^{-1}\right)$ with propagated uncertainties.

\begin{tabular}{lrrr|rrr}
\hline & \multicolumn{3}{c|}{ Measured (mean $\pm \mathrm{SD}$ ) } & \multicolumn{3}{c}{ Estimated (mean $\pm \mathrm{SE}$ ) } \\
\cline { 2 - 7 } Period & $R_{\text {soil }}$ & $R_{\text {re }}$ & $R_{\text {rme }}$ & $R_{\text {het }}$ & $R_{\text {myc }}$ & $R_{\text {rhizo }}$ \\
\hline Active & $7.7 \pm 1.6$ & $5.1 \pm 1.5$ & $3.9 \pm 1.1$ & $1.7 \pm 1.1$ & $1.0 \pm 1.2$ & $5.1 \pm 1.1$ \\
Drying & $5.7 \pm 2.0$ & $3.8 \pm 1.5$ & $2.9 \pm 0.6$ & $2.9 \pm 0.7$ & $0.6 \pm 0.9$ & $2.1 \pm 0.8$ \\
Drought & $3.2 \pm 1.1$ & $2.3 \pm 0.4$ & $1.9 \pm 0.4$ & $1.7 \pm 0.5$ & $0.3 \pm 0.6$ & $1.1 \pm 0.5$ \\
Wetting & $4.8 \pm 1.7$ & $4.3 \pm 1.5$ & $2.6 \pm 1.2$ & $1.5 \pm 0.6$ & $1.0 \pm 0.7$ & $2.3 \pm 0.7$ \\
Re-greening & $3.8 \pm 1.0$ & $2.4 \pm 0.8$ & $2.0 \pm 1.1$ & $1.1 \pm 0.4$ & $0.3 \pm 0.5$ & $2.4 \pm 0.4$ \\
Total study period & $5.0 \pm 2.1$ & $3.8 \pm 1.6$ & $2.6 \pm 1.2$ & $1.8 \pm 0.6$ & $0.7 \pm 0.8$ & $2.6 \pm 0.7$ \\
\hline
\end{tabular}




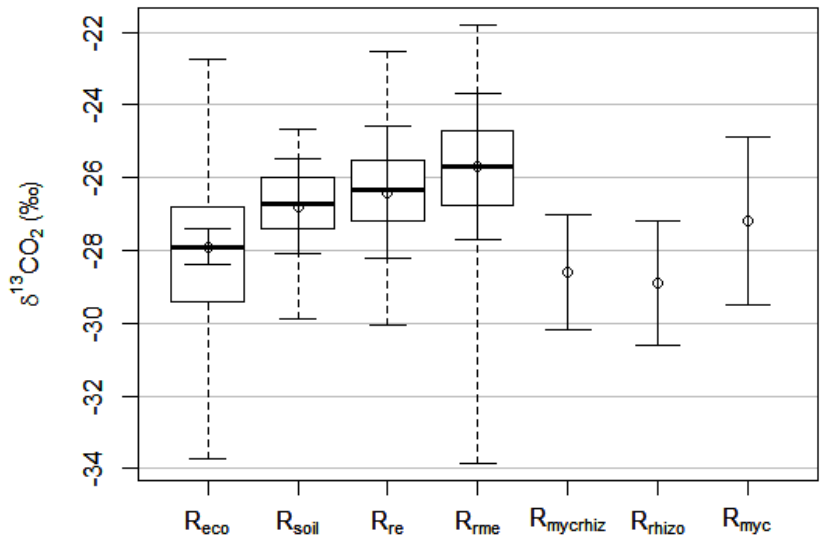

Figure 2. Measured $\left(R_{\mathrm{eco}}, R_{\text {soil }}, R_{\mathrm{re}}, R_{\text {rme }}\right)$ and estimated $\left(R_{\text {mycrhiz }}, R_{\text {rhizo }}, R_{\text {myc }}\right) \delta^{13} \mathrm{C}$ values of the respiration components. Horizontal black lines in boxes show medians and dashed whiskers show data extremes. Open circles and solid whiskers show mean \pm propagated standard errors. Gray horizontal lines show $y$ major values.

than $R_{\text {soil }}$, especially shortly after rain events. The lowest daily average total soil $\mathrm{CO}_{2}$ efflux was measured on 15 August $\left(2.22 \mu \mathrm{mol} \mathrm{CO} \mathrm{Cm}^{-2} \mathrm{~s}^{-1}\right)$, while the lowest daily average $R_{\mathrm{re}}$ and $R_{\mathrm{rme}}$ values were observed on 2 October $\left(1.25 \mu \mathrm{mol} \mathrm{CO} \mathrm{m}^{-2} \mathrm{~s}^{-1}\right)$ and 2 November $\left(1.04 \mu \mathrm{mol} \mathrm{CO} \mathrm{Cm}^{-2} \mathrm{~s}^{-1}\right)$, respectively. The highest values of soil $\mathrm{CO}_{2}$ effluxes were measured in May in all treatments ( $R_{\text {soil }}, R_{\text {re }}$ and $\left.R_{\text {rme }}\right)$. Sudden increases in $R_{\text {re }}$ and $R_{\text {rme }}$ were observed shortly after rain events but $R_{\text {soil }}$ showed slower (but more persistent) response to precipitation (Fig. 1c).

Isotopic signature of $R_{\text {eco }}$ was the lowest in May and June, increased in July and August and decreased again in October and November (Fig. 1e). $\delta^{13} C_{R_{\text {eco }}}$ showed clear responses to precipitation pulses with sudden declines being observed during the rain events. Chamber-based $\delta^{13} \mathrm{C}_{R_{\text {soil }}}$ showed similar changes during the study period. $\delta^{13} \mathrm{C}_{R_{\mathrm{rme}}}$ and $\delta^{13} \mathrm{C}_{R_{\mathrm{re}}}$ showed large scatter during the whole study period with no clear and detectable trends (Fig. 1d). Differences between $\delta^{13} \mathrm{C}_{R_{\text {soil }}}$ and $\delta^{13} \mathrm{C}_{R_{\text {rme }}}$ were the largest in the active period and the smallest under drought conditions.

According to the NEE, SWC values and isotopic signals we distinguished five periods within the study period: an active period from 15 May to 20 June, a drying (stress development) period from 21 June to 22 July, a drought period from 23 July to 19 August, a wetting (stress release) period from 20 August to 16 September and a re-greening (recovery) period from 17 September to the end of the study period (11 November; Fig. 1).

\section{$3.2 \quad \delta^{13} \mathrm{C}$ of the respiration components}

Figure 2 shows the measured and estimated $\delta^{13} \mathrm{C}$ values of the different soil $\mathrm{CO}_{2}$ efflux components. $\delta^{13} \mathrm{C}_{R_{\mathrm{rme}}}$ was the highest, while $\delta^{13} \mathrm{C}_{R_{\text {soil }}}$ was the lowest, suggesting that it

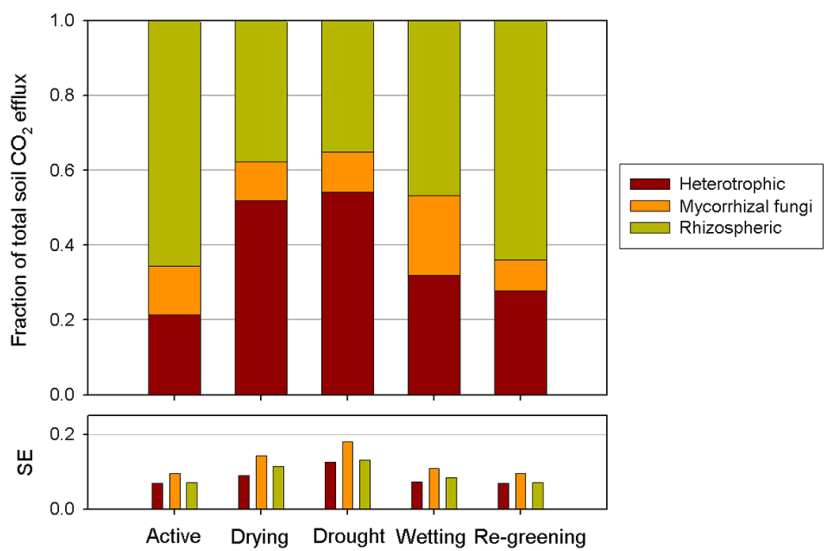

Figure 3. Relative contributions made by rhizospheric, mycorrhizal fungi and heterotrophic components to the total soil respiration in the different parts of the vegetation period (15 May 2013-12 November 2013) at Bugac site. Propagated uncertainties of each estimate are shown in the lower panel. Gray horizontal lines show $y$ major values.

was the rhizospheric respiration that was the most substantially depleted, while heterotrophic respiration was the least depleted in ${ }^{13} \mathrm{C}$. Mean values of $\delta^{13} \mathrm{C}_{R_{\mathrm{eco}}}, \delta^{13} \mathrm{C}_{R_{\text {soil }}}, \delta^{13} \mathrm{C}_{R_{\mathrm{re}}}$ and $\delta^{13} \mathrm{C}_{R_{\text {rme }}}$ were $-27.9 \pm 0.5,-26.8 \pm 1.3,-26.4 \pm 1.8$ and $-25.7 \pm 2 \%$ (mean $\pm \mathrm{SE}$ ), respectively. The estimated isotopic signals of the respiration of mycorrhizospheric $\left(\delta^{13} \mathrm{C}_{R_{\text {mychiz }}}\right)$, rhizospheric $\left(\delta^{13} \mathrm{C}_{R_{\text {rhizo }}}\right)$ and mycorrhizal fungi components $\left(\delta^{13} \mathrm{C}_{R_{\text {myc }}}\right)$ were $-28.6 \pm 1.6$, $-28.9 \pm 1.7$ and $-27.2 \pm 2.3 \%$ (estimate $\pm \mathrm{SE}$ ), respectively (Fig. 2)

While $36 \%$ of the variation in $\delta^{13} \mathrm{C}_{R_{\text {soil }}}$ was explained by SWC $\left(\delta^{13} \mathrm{C}_{R_{\text {soil }}}=-0.1267 \times \mathrm{SWC}-25.537, R^{2}=0.36\right.$, $P<0.0001$ ), only $3 \%$ of the variation of $\delta^{13} \mathrm{C}_{R_{\mathrm{rme}}}$ was explained by SWC and there was no correlation between $\delta^{13} C_{R_{\mathrm{re}}}$ and SWC. Similar results were obtained between $T_{\mathrm{S}}$ and the isotopic signals but the correlation was weaker $\left(\delta^{13} C_{R_{\text {soil }}}=0.1056 \times T_{\mathrm{S}}-28.588, R^{2}=0.11, P<0.0001\right)$. Daily minimum NEE (NEEmin, Fig. 1b) explained $29 \%$ of the variation in $\delta^{13} \mathrm{C}_{R_{\text {soil }}}\left(\delta^{13} \mathrm{C}_{R_{\text {soil }}}=0.0941 \times \mathrm{NEEmin}\right.$ $\left.-26.245, R^{2}=0.29, P<0.0001\right)$ but no correlation was found between NEEmin and $\delta^{13} \mathrm{C}_{R_{\mathrm{rme}}}$ and between NEEmin and $\delta^{13} \mathrm{C}_{R_{\mathrm{re}}}$.

\subsection{Fraction of the different components in total soil respiration during the vegetation period}

Two end-member mixing models (Eqs. 3 and 4) were used to estimate the relative contributions of rhizospheric, mycorrhizal fungi and heterotrophic components to total soil respiration during the study period. The estimated contributions by the different components were $50 \pm 6,13 \pm 8$ and $37 \pm 6 \%$ (mean $\pm \mathrm{SE}$ ) for the rhizospheric, mycorrhizal fungi and heterotrophic components, respectively. The au- 


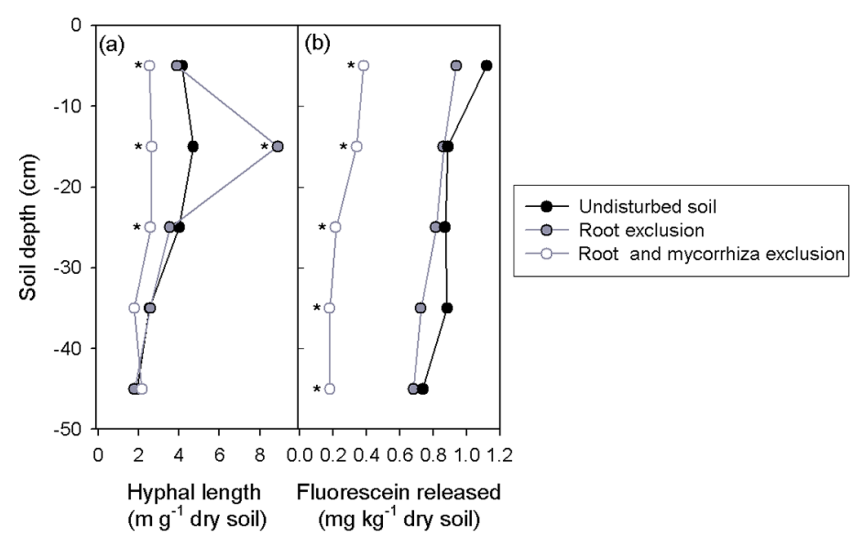

Figure 4. (a) Mean hyphal length ( $\mathrm{mg}^{-1}$ dry soil) and (b) mean microbial activity expressed as fluorescein released $\left(\mathrm{mg} \mathrm{kg}^{-1}\right.$ dry soil) in the undisturbed soil, root exclusion and root and mycorrhiza exclusion in different soil depths. Asterisks denote significant differences from undisturbed soil determined by the Tukey honest significant difference test.

totrophic component (mycorrhizospheric component) of soil respiration showed significant decrease during the drying and drought periods. Rhizospheric component was the most sensitive to drying and drought. Average contributions by the rhizospheric component to total soil $\mathrm{CO}_{2}$ efflux decreased from $66 \pm 7 \%$ (mean \pm SE) in the active period to $35 \pm 13 \%$ during the drought period (Fig. 3). After drought rhizospheric contributions increased again and become dominant during the re-greening period in autumn $63 \pm 7 \%$ (mean \pm SE). During the transient (drying and wetting) periods the rhizospheric contributions to the total soil $\mathrm{CO}_{2}$ efflux were $38 \pm 11$ and $46 \pm 8 \%$, respectively. Relative mycorrhizal contributions were between 8 and $21 \%$ during the whole study period, with the highest contribution $(21 \pm 11 \%$; mean $\pm \mathrm{SE}$ ) during the wetting period. Heterotrophic contributions to soil respiration were the lowest in the active period $(21 \pm 7 \%)$ and the highest under drought $(54 \pm 13 \%$; Fig. 3).

Changes in soil $\mathrm{CO}_{2}$ effluxes showed similar responses to drying and drought conditions as isotopic signals. Average $R_{\text {soil }}$ decreased by $60 \%$ (referenced to the average during the active period) as a response to drought, while $R_{\text {re }}$ and $R_{\text {rme }}$ showed declines of 56 and $52 \%$ respectively, suggesting that declines in root respiration were substantially larger than those in $R_{\text {soil }}(60 \%)$.

The estimated rates of rhizospheric, mycorrhizal fungi and heterotrophic components (Eqs. 5-7) are shown in Table 2. Pearson correlation coefficients pairing the estimated respiration rates and their possible driving variables (NEE, $T_{\mathrm{s}}$, SWC) showed significant negative correlation between $R_{\text {rhiz }}$ and NEE $(R=-0.94, p<0.05)$ and a significant positive correlation between $R_{\text {rhiz }}$ and SWC $(R=0.82, p<0.0 .5)$. $R_{\text {het }}$ changed with $T_{\mathrm{S}}$ but the correlation was not significant.

\subsection{Microbial biomass and activity}

Hyphal length (on dry soil weight basis) was significantly lower in the upper layers of root- and mycorrhiza-excluded soil than in undisturbed soil, while it was significantly higher in root-excluded plots at $10-20 \mathrm{~cm}$ depth. Hyphal length in the root-excluded soil was similar to undisturbed soil in the other soil layers. Fluorescein values were significantly lower in all soil layers in the root- and mycorrhiza-excluded plots than in the undisturbed soil. Fluorescein values in the rootexcluded plots were also lower than in undisturbed soil but this difference was not significant (Fig. 4).

\section{Discussion}

Our approach combined the root- and root- and mycorrhizaexclusion treatments with isotopic measurements. The aim of this combination was to assess the contributions made by the heterotrophic and autotrophic components in soil $\mathrm{CO}_{2}$ efflux of the undisturbed soil. Although the root and mycorrhiza exclusion caused large disturbances in soil structure by inserting the tubes into the soil, we used these treatments only for identifying the isotopic signals of the investigated components. All of the estimated contributions to soil $\mathrm{CO}_{2}$ efflux by rhizospheric, mycorrhizal fungi and heterotrophic components were applied for the undisturbed soil.

\subsection{Estimated contributions made by the different components to the total soil $\mathrm{CO}_{2}$ efflux and effect of drought on $\mathrm{CO}_{2}$ effluxes and $\delta^{13} \mathrm{C}$ values}

While the percentages of the autotrophic component in the total soil $\mathrm{CO}_{2}$ efflux were $63 \pm 6 \%$ on average (rhizospheric and mycorrhizal fungi components: $50 \pm 6$ and $13 \pm 8 \%$, respectively), thus much higher than the average percentage of the heterotrophic $(37 \pm 6 \%)$ component, the contributions by the different components showed significant changes during the growing season. In other studies conducted in grassland ecosystems the estimated yearly average ratio of the autotrophic component was found to be lower accounting for $38-52 \%$ of the total soil respiration (Bao et al., 2010; Heinemeyer et al., 2012), while reaching $74 \%$ during the growing season in a prairie grassland (Gomez-Casanovas et al., 2012) and $60-74 \%$ in an arid perennial grassland (Carbone et al., 2008). Our study was conducted from May to the beginning of November; therefore we can assume considering the lower vegetation activity in the dormant season (Nagy et al., 2007) that the contribution of the autotrophic component could be lower while that of the heterotrophic component higher for the whole year than the estimations for the growing season.

Soil $\mathrm{CO}_{2}$ effluxes decreased in all treatments $\left(R_{\text {soil }}, R_{\mathrm{re}}\right.$, $R_{\text {rme }}$ ) under dry conditions, the largest decline being observed in total soil respiration $\left(R_{\text {soil }}\right)$; therefore a strong response of the autotrophic component to drought could be assumed. The measured isotopic signals also showed decreas- 
ing autotrophic contributions to $\mathrm{CO}_{2}$ efflux during soil drying. $\delta^{13} \mathrm{C}_{R_{\text {soil }}}$ showed negative responses to SWC and was more enriched when SWC was low, while $\delta^{13} \mathrm{C}$ of the rootand mycorrhiza-excluded respiration $\left(R_{\mathrm{rme}}\right)$ showed no response. Since $\delta^{13} C_{R_{\text {eco }}}$ was the lowest of the measured isotopic signals it can be assumed that the isotopic signals of the aboveground respiration could be the most depleted $\delta^{13} \mathrm{C}$. Therefore, the observed increase in $\delta^{13} \mathrm{C}_{R_{\text {eco }}}$ and $\delta^{13} \mathrm{C}_{R_{\text {soil }}}$ values during the drying period and during the drought also showed the decline of both the above- and belowground autotrophic components. The same phenomenon was shown by the modeling results with the smallest contribution made by the rhizospheric component estimated for the drought period ( $35 \pm 13 \%$; mean $\pm \mathrm{SE}$ ), while the highest for the active period ( $66 \pm 7 \%$; mean $\pm \mathrm{SE})$. Fractions of the heterotrophic respiration were the highest during drought $(54 \pm 13 \%$ mean \pm SE) and the mycorrhizal fungi respiration showed only a small decrease during drought compared to the active period (from $13 \pm 10$ to $11 \pm 18 \%$;), suggesting that the non-rootassociated microbes and mycorrhizal filaments were less sensitive to water shortages than the rhizosphere. Soil aggregates are expected to provide microhabitats for soil organisms that should be moist enough for those organisms to thrive even under drought (Davidson et al., 2012). Since there was an absence in plant photosynthetic supply during drought period, mycorrhizal fungi component is expected to use stored carbon for respiration (van der Heijden et al., 2008).

Low $\delta^{13} \mathrm{C}_{R_{\text {soil }}}$ and $\delta^{13} \mathrm{C}_{R_{\text {eco }}}$ values were measured in the wetting and re-greening periods due to the drought-induced fall of the fresh litter to the surface as fresh plant material could be more depleted than the old litter (Bowling et al., 2002). The declines in $\delta^{13} C_{R_{\text {soil }}}$ and $\delta^{13} \mathrm{C}_{R_{\text {eco }}}$ immediately after the rain events during drying and drought periods could also be explained by the wetting of the litter layer, exposing relatively fresh substrate to degradation for short periods. This phenomenon could also cause an overestimation in contributions made by the depleted components (rhizospheric) during rain events. Since the rhizospheric contribution estimated for the re-greening period was high it is assumed that this result was obtained partly due to the increased amount of fresh litter. Similar results were obtained in a tallgrass prairie by Gomez-Casanovas et al. (2012), where the autotrophic components were more sensitive to soil drying than the heterotrophic ones. In contrast, Carbone et al. (2008) found more sensitive response by the heterotrophic component in an arid $(<150 \mathrm{~mm}$ annual precipitation) perennial grassland. Fractions of autotrophic components were reported to increase in response to drought in a woodland ecosystem, supposing that the signature of the recent photosynthetic supply became enriched during drought and that could also explain the increase in the soil-respired $\mathrm{CO}_{2}$ (Casals et al., 2011). A drought-induced increase in $\delta^{13} \mathrm{C}$ of root respiration of trees was also assumed in a recent study (Risk et al., 2012), suggesting that the isotopic signals of the assimilates, and thus the signals of the autotrophic component, might also increase. In our study, $R_{\text {rme }} / R_{\text {soil }}$ showed significant positive correlation with $\delta^{13} C_{R_{\text {soil }}}$ (the regression was used to estimate $\delta^{13} \mathrm{C}_{R_{\text {mycrhiz }}}$, Fig. S4), so $\delta^{13} \mathrm{C}_{R_{\text {soil }}}$ was high if the fraction of heterotrophic $\mathrm{CO}_{2}$ efflux to the total soil $\mathrm{CO}_{2}$ efflux was found to be high. Moreover, NEEmin values were close to zero during drought (average daily minimum NEE was $-0.91 \mu \mathrm{mol} \mathrm{CO} \mathrm{CO}_{2} \mathrm{~m}^{-2} \mathrm{~s}^{-1}$ ), showing the lack of the photosynthetic supply in this period. Photosynthetic $\mathrm{CO}_{2}$ uptake of this vegetation was found to be sensitive to drought conditions (Nagy et al., 2007) and it can act as a driver of the soil $\mathrm{CO}_{2}$ production and efflux (Balogh et al., 2015). The observed strong correlation between the estimated rhizospheric respiration and NEE can also be explained by the interacting effects of drought and photosynthetic supply of respiration. These findings support the concept that in the grasslands under study the autotrophic respiration component was more sensitive to soil drying and its activity determined the isotopic signals of the total soil respiration during the study period.

According to these studies and to our results we can assume that the different vegetation types may respond differently to drought: woodlands may increase their autotrophic contribution while grasslands may decrease it (Casals et al., 2011; Gomez-Casanovas et al., 2012; Risk et al., 2012). Plants with different rooting habits have different water availability during dry periods (van der Molen et al., 2011), which could explain the differences between the different ecosystems in their response to drought.

\subsection{Measured and estimated isotopic signals of the soil respiration components}

Measured and calculated $\delta^{13} \mathrm{C}$ values of the different respiration components showed differences similar to the ones reviewed by Bowling et al. (2008). $\delta^{13} \mathrm{C}_{R_{\text {eco }}}$ (containing also the signal from aboveground green biomass) was the most depleted, while $\delta^{13} \mathrm{C}_{R_{\mathrm{rme}}}$ (heterotrophic components only) was the least depleted. $\delta^{13} \mathrm{C}$ of the root- and mycorrhizaexcluded respiration was similar to $\mathrm{SOM} \delta^{13} \mathrm{C}$ measured in a previous study (Denef et al., 2013): -25 and $-26 \%$ in the topsoil layers (without the litter layer). $\mathrm{CO}_{2}$ effluxes from mycorrhizal fungi were expected to be more enriched in ${ }^{13} \mathrm{C}$ relative to the total soil respiration (about $+3 \%$; Bowling et al., 2008). Estimated $\delta^{13} \mathrm{C}$ of mycorrhizal fungi component was $-27.2 \pm 2.3 \%$ o (estimate $\pm \mathrm{SE}$ ), which is $1.7 \%$ o higher than the rhizospheric component $(-28.9 \pm 1.7 \%$; estimate $\pm \mathrm{SE}$ ).

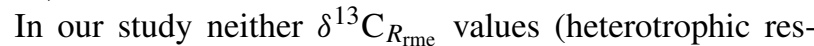
piration) nor $\delta^{13} \mathrm{C}_{R_{\mathrm{re}}}$ values (heterotrophic + mycorrhizal fungi respiration) showed correlation with SWC but $\delta^{13} \mathrm{C}_{R_{\text {soil }}}$ (total soil respiration) showed significant negative correlation with SWC. We can assume that $\delta^{13} \mathrm{C}$ of heterotrophic respiration was not influenced by SWC changes during the growing season as it was found also by other studies (Phillips and Nickerson, 2010; Risk et al., 2012). Furthermore, the lack 
of correlation with the present study also suggests that soilmoisture-induced changes in diffusivity (disequilibrium effect due to changing soil moisture) were not large enough to affect the measured $\delta^{13} \mathrm{C}$ values.

\subsection{Microbial investigations}

High hyphal density was maintained in $R_{\text {re }}$ plots and low but still significant microbial activities (SOM decomposition)

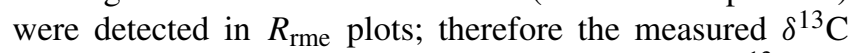
values characterized the sources of the root-free $\left(\delta^{13} \mathrm{C}_{R_{\mathrm{re}}}\right)$ and root- and mycorrhiza-free $\left(\delta^{13} \mathrm{C}_{R_{\mathrm{rme}}}\right)$ soils. The fact that very high amounts of hyphae were found in the root-excluded soil in the $10-20 \mathrm{~cm}$ layer proved that mycorrhizal fungi filaments were able to penetrate through the inox mesh and supported significant microbial activity. Grasses have extensive fibrous root systems with moderate to high levels of mycorrhizal colonization (van der Heijden et al., 2015). The range of AM hyphal lengths found in this study (1.9$8.8 \mathrm{~m} \mathrm{~g}^{-1}$ soil) was similar to that reported in the literature (e.g., Mummey and Rillig, 2008). The higher hyphal densities found in root-free soil might have been related to the higher availability of SOM-derived nutrients and to more space without the roots (i.e., lack of competition). According to our results, a significant amount of $\mathrm{CO}_{2}$ was respired from mycorrhizal filaments in the undisturbed soil, with a $12-31 \%$ share in the respiration carried out by the autotrophic component.

Values of fluorescein in root-excluded plots were similar to those measured in the undisturbed soil probably because hyphae of AM fungi provide an increased area for interaction with other microorganisms (hyphosphere; Andrade et al., 1997) but were much lower in root- and mycorrhizaexcluded soil. These results support the component estimations showing the significant activities of root-associated microorganisms.

\section{Conclusions}

In the dry grasslands investigated in our study all three components of the soil $\mathrm{CO}_{2}$ effluxes decreased, following different dynamics under drought conditions. Both the measured $\mathrm{CO}_{2}$ effluxes and the isotopic signals showed similar results regarding the component responses. The strongest decrease in response to drought was seen in rhizospheric respiration (relative contribution to the total respiration decreased from $66 \pm 7$ to $35 \pm 13 \%$; mean $\pm \mathrm{SE}$ ), while the relative contribution to the total soil respiration by the heterotrophic components increased during soil drying. During drought the contribution of the heterotrophic component was found to be the highest ( $54 \pm 8 \%$; mean $\pm \mathrm{SE})$. Mycorrhizal fungi respiration had its highest share in soil respiration $(21 \pm 11 \%$; mean $\pm \mathrm{SE}$ ) in the wetting period after drought. According to these results the autotrophic component of the soil respiration is more sensitive to drought than the heterotrophic one in the dry grassland ecosystem studied. Thus, carbon source activities during drought periods identified by NEE measurements originated from carbon sources already stored, thereby decreasing the carbon content of the soil.

Drought events are expected to be more frequent in central Europe in the future, and it is expected that the productivity of grassland ecosystems may strongly respond to projected dryness, influencing the carbon cycle of the ecosystems. Since potential productivity is generally linked to soil carbon content a pronounced decrease in SOM due to the enhanced activity of the heterotrophic component under drought may directly affect the long-term productivity of grasslands.

\section{Data availability}

The dataset depicted in Fig. 1 is available at http://nofi.szie. $\mathrm{hu} / \mathrm{sites} / \mathrm{default} /$ files/fig 1 data.csv. Other requests can be sent to the corresponding author (balogh.janos@mkk.szie.hu).

\section{The Supplement related to this article is available online at doi:10.5194/bg-13-5171-2016-supplement.}

Author contributions. János Balogh, Marianna Papp, Krisztina Pintér and Zoltán Nagy conceived and designed the experiment. Marianna Papp, Krisztina Pintér and Katalin Posta performed the experiment. János Balogh, Szilvia Fóti, Werner Eugster and Zoltán Nagy analyzed the data and wrote the paper, but all co-authors contributed to writing.

Acknowledgements. The authors are grateful to the editor and to the three reviewers who provided constructive comments and suggestions that improved the paper. The authors gratefully acknowledge the financial support of the projects OTKA-PD 100575, OTKA-PD 105944, Research Centre of Excellence (11476-3/2016/FEKUT) and KTIA_AIK_12-1-2012-0012. János Balogh and Szilvia Fóti acknowledge the support of the János Bolyai Research Scholarship of the Hungarian Academy of Sciences. Isotopic measurements were supported by Gábor Baross Programme (REG-KM-09-12009-0029).

Edited by: U. Seibt

Reviewed by: J. Grünzweig and two anonymous referees

\section{References}

Adam, G. and Duncan, H.: Development of a sensitive and rapid method for the measurement of total microbial activity using fluorescein diacetate (FDA) in a range of soils, Soil Biol. Biochem., 33, 943-951, 2001. 
Andrade, G., Mihara, K. L., Linderman, R. G., and Bethlenfalvay, G. J.: Bacteria from rhizosphere and hyphosphere soils of different arbuscular-mycorrhizal fungi, Plant Soil, 192, 71-79, doi:10.1023/A:1004249629643, 1997.

Bååth, E. and Söderström, B.: The significance of hyphal diameter in calculation of fungal biovolume, Oikos, 33, 11-14, 1979.

Bahn, M., Rodeghiero, M., Anderson-Dunn, M., Dore, S., Gimeno, C., Drösler, M., Williams, M., Ammann, C., Berninger, F., Flechard, C., Jones, S., Balzarolo, M., Kumar, S., Newesely, C., Priwitzer, T., Raschi, A., Siegwolf, R., Susiluoto, S., Tenhunen, J., Wohlfahrt, G., and Cernusca, A.: Soil Respiration in European Grasslands in Relation to Climate and Assimilate Supply, Ecosystems, 11, 1352-1367, doi:10.1007/s10021-008-91980, 2008.

Balogh, J., Pintér, K., Fóti, S., Cserhalmi, D., Papp, M., and Nagy, Z.: Dependence of soil respiration on soil moisture, clay content, soil organic matter, and $\mathrm{CO}_{2}$ uptake in dry grasslands, Soil Biol. Biochem., 43, 1006-1013, doi:10.1016/j.soilbio.2011.01.017, 2011.

Balogh, J., Fóti, S., Pintér, K., Burri, S., Eugster, W., Papp, M., and Nagy, Z.: Soil $\mathrm{CO}_{2}$ efflux and production rates as influenced by evapotranspiration in a dry grassland, Plant Soil, 388, 157-173, doi:10.1007/s11104-014-2314-3, 2015.

Bao, F., Zhou, G., Wang, F., and Sui, X.: Partitioning soil respiration in a temperate desert steppe in Inner Mongolia using exponential regression method, Soil Biol. Biochem., 42, 2339-2341, doi:10.1016/j.soilbio.2010.08.033, 2010.

Barcza, Z., Haszpra, L., and Kondo, H.: Carbon exchange of grass in Hungary, Tellus B, 55, 187-196, doi:10.1034/j.16000889.2003.00014.x, 2003.

Bardgett, R. D., Freeman, C., and Ostle, N. J.: Microbial contributions to climate change through carbon cycle feedbacks, ISME J., 2, 805-814, doi:10.1038/ismej.2008.58, 2008.

Blagodatsky, S. and Smith, P.: Soil physics meets soil biology: Towards better mechanistic prediction of greenhouse gas emissions from soil, Soil Biol. Biochem., 47, 78-92, doi:10.1016/j.soilbio.2011.12.015, 2012.

Bowling, D., McDowell, N., Bond, B., Law, B., and Ehleringer, J.: ${ }^{13} \mathrm{C}$ content of ecosystem respiration is linked to precipitation and vapor pressure deficit, Oecologia, 131, 113-124, doi:10.1007/s00442-001-0851-y, 2002.

Bowling, D. R., Pataki, D. E., and Randerson, J. T.: Carbon isotopes in terrestrial ecosystem pools and $\mathrm{CO}_{2}$ fluxes, New Phytol., 178, 24-40, doi:10.1111/j.1469-8137.2007.02342.x, 2008.

Carbone, M. S., Winston, G. C., and Trumbore, S. E.: Soil respiration in perennial grass and shrub ecosystems: Linking environmental controls with plant and microbial sources on seasonal and diel timescales, J. Geophys. Res., 113, G02022, doi:10.1029/2007JG000611, 2008.

Carbone, M. S., Still, C. J., Ambrose, A. R., Dawson, T. E., Williams, A. P., Boot, C. M., Schaeffer, S. M., and Schimel, J. P.: Seasonal and episodic moisture controls on plant and microbial contributions to soil respiration, Oecologia, 167, 265-78, doi:10.1007/s00442-011-1975-3, 2011.

Casals, P., Lopez-Sangil, L., Carrara, A., Gimeno, C., and Nogués, S.: Autotrophic and heterotrophic contributions to short-term soil $\mathrm{CO}_{2}$ efflux following simulated summer precipitation pulses in a Mediterranean dehesa, Global Biogeochem. Cy., 25, GB3012, doi:10.1029/2010GB003973, 2011.
Chen, S., Lin, G., Huang, J., and Jenerette, G. D.: Dependence of carbon sequestration on the differential responses of ecosystem photosynthesis and respiration to rain pulses in a semiarid steppe, Glob. Change Biol., 15, 2450-2461, doi:10.1111/j.13652486.2009.01879.x, 2009.

Davidson, E. A., Samanta, S., Caramori, S. S., and Savage, K.: The Dual Arrhenius and Michaelis-Menten kinetics model for decomposition of soil organic matter at hourly to seasonal time scales, Glob. Change Biol., 18, 371-384, doi:10.1111/j.13652486.2011.02546.x, 2012.

Denef, K., Galdo, I., Venturi, A., and Cotrufo, M.: Assessment of Soil C and N Stocks and Fractions across 11 European Soils under Varying Land Uses, Open J. Soil Sci., 3, 297-313, 2013.

Epron, D.: Separating autotrophic and heterotrophic components of soil respiration: lessons learned from trenching and related root exclusion experiments, in Soil Carbon Dynamics: An Integrated Methodology, edited by: Bahn, M., Heinemeyer, A., and Kutsch, W., Cambridge University Press, 289-310, 2009.

Farkas, C., Alberti, G., Balogh, J., Barcza, Z., Birkas, M., Czobel, S., Davis, K. J., Fuehrer, E., Gelybo, G., Grosz, B., Kljun, N., Koos, S., Machon, A., Marjanovic, H., Nagy, Z., Peressotti, A., Pinter, K., Toth, E., and Horvath, L.: Methodologies, in Atmospheric Greenhouse Gases: The Hungarian Perspective, edited by: Haszpra, L., 65-90, Springer, New York, 2011.

Fassbinder, J. J., Griffis, T. J., and Baker, J. M.: Interannual, seasonal, and diel variability in the carbon isotope composition of respiration in a $\mathrm{C}_{3} / \mathrm{C}_{4}$ agricultural ecosystem, Agr. Forest Meteorol., 153, 144-153, doi:10.1016/j.agrformet.2011.09.018, 2011.

Gamnitzer, U., Moyes, A. B., Bowling, D. R., and Schnyder, H.: Measuring and modelling the isotopic composition of soil respiration: insights from a grassland tracer experiment, Biogeosciences, 8, 1333-1350, doi:10.5194/bg-8-1333-2011, 2011.

Gomez-Casanovas, N., Matamala, R., Cook, D. R., and GonzalezMeler, M. a.: Net ecosystem exchange modifies the relationship between the autotrophic and heterotrophic components of soil respiration with abiotic factors in prairie grasslands, Glob. Change Biol., 18, 2532-2545, doi:10.1111/j.13652486.2012.02721.x, 2012.

Heinemeyer, A., Tortorella, D., Petrovičová, B., and Gelsomino, A.: Partitioning of soil $\mathrm{CO}_{2}$ flux components in a temperate grassland ecosystem, Eur. J. Soil Sci., 63, 249-260, doi:10.1111/j.1365-2389.2012.01433.x, 2012.

Hiiesalu, I., Partel, M., Davison, J., Gerhold, P., Metsis, M., Moora, M., Öpik, M., Vasar, M., Zobel, M., and Wilson, S. D.: Species richness of arbuscular mycorrhizal fungi: Associations with grassland plant richness and biomass, New Phytol., 203, 233244, doi:10.1111/nph.12765, 2014.

Hoover, D., Knapp, A., and Smith, M.: Resistance and resilience of a grassland ecosystem to climate extremes, Ecology, 95, 26462656, doi:10.1890/13-2186.1, 2014.

Hopkins, F., Gonzalez-Meler, M. A., Flower, C. E., Lynch, D. J., Czimczik, C., Tang, J., and Subke, J.-A.: Ecosystem-level controls on root-rhizosphere respiration, New Phytol., 199, 339-51, 2013.

Knohl, A., Werner, R. A., Brand, W. A., and Buchmann, N.: Shortterm variations in $\delta^{13} \mathrm{C}$ of ecosystem respiration reveals link between assimilation and respiration in a deciduous forest, Oecologia, 142, 70-82, doi:10.1007/s00442-004-1702-4, 2005. 
Koncz, P., Besnyői, V., Csathó, A. I., Nagy, J., Szerdahelyi, T., Tóth, Z., Pintér, K., Balogh, J., Nagy, Z., and Bartha, S.: Effect of grazing and mowing on the microcoenological composition of semiarid grassland in Hungary, Appl. Ecol. Environ. Res., 12, 563575, doi:10.15666/aeer/1202_563575, 2014.

Lo, E.: Gaussian Error Propagation Applied To Ecological Data: Post-Ice-Storm-Downed Woody Biomass, Ecol. Monogr., 75, 451-466, doi:10.1890/05-0030, 2005.

Midwood, A. J. and Millard, P.: Challenges in measuring the $\delta^{13} \mathrm{C}$ of the soil surface $\mathrm{CO}_{2}$ efflux, Rapid Commun. Mass Spectrom., 25, 232-242, doi:10.1002/rcm.4857, 2011.

Moyano, F., Kutsch, W., and Schulze, E.: Response of mycorrhizal, rhizosphere and soil basal respiration to temperature and photosynthesis in a barley field, Soil Biol. Biochem., 39, 843-853, doi:10.1016/j.soilbio.2006.10.001, 2007.

Moyano, F., Atkin, O., Bahn, M., Bruhn, D., Burton, A., Heinemeyer, A., WL, K., and Wieser, G.: Respiration from roots and the mycorrhizosphere, in Soil Carbon Dynamics: An Integrated Methodology, edited by: Bahn, M., Heinemeyer, A., and Kutsch, W. L., 234-288, Cambridge University Press, 2009.

Moyano, F. E., Manzoni, S., and Chenu, C.: Responses of soil heterotrophic respiration to moisture availability: An exploration of processes and models, Soil Biol. Biochem., 59, 72-85, doi:10.1016/j.soilbio.2013.01.002, 2013.

Moyes, A. B., Gaines, S. J., Siegwolf, R. T. W., and Bowling, D. R.: Diffusive fractionation complicates isotopic partitioning of autotrophic and heterotrophic sources of soil respiration, Plant Cell Environ., 33, 1804-19, doi:10.1111/j.1365-3040.2010.02185.x, 2010.

Mummey, D. L. and Rillig, M. C.: Spatial characterization of arbuscular mycorrhizal fungal molecular diversity at the submetre scale in a temperate grassland, FEMS Microbiol. Ecol., 64, 260270, doi:10.1111/j.1574-6941.2008.00475.x, 2008.

Nagy, Z., Pintér, K., Czóbel, S., Balogh, J., Horváth, L., Fóti, S., Barcza, Z., Weidinger, T., Csintalan, Z., Dinh, N. Q., Grosz, B., and Tuba, Z.: The carbon budget of semi-arid grassland in a wet and a dry year in Hungary, Agr. Ecosyst. Environ., 121, 21-29, doi:10.1016/j.agee.2006.12.003, 2007.

Nagy, Z., Pintér, K., Pavelka, M., Darenová, E., and Balogh, J.: Carbon fluxes of surfaces vs. ecosystems: advantages of measuring eddy covariance and soil respiration simultaneously in dry grassland ecosystems, Biogeosciences, 8, 2523-2534, doi:10.5194/bg-8-2523-2011, 2011.

Nickerson, N. and Risk, D.: A numerical evaluation of chamber methodologies used in measuring the $\delta^{13} \mathrm{C}$ of soil respiration, Rapid Commun. Mass Spectrom., 23, 2802-2810, doi:10.1002/rcm.4189, 2009.

Nickerson, N., Egan, J., and Risk, D.: Iso-FD: A novel method for measuring the isotopic signature of surface flux, Soil Biol. Biochem., 62, 99-106, doi:10.1016/j.soilbio.2013.03.010, 2013.

Parton, W., Morgan, J., Smith, D., Del Grosso, S., Prihodko, L., Lecain, D., Kelly, R., and Lutz, S.: Impact of precipitation dynamics on net ecosystem productivity, Glob. Change Biol., 18, 915-927, doi:10.1111/j.1365-2486.2011.02611.x, 2012.

Phillips, C. and Nickerson, N.: Soil moisture effects on the carbon isotope composition of soil respiration, Rapid Commun. Mass Spectrom., 1271-1280, doi:10.1002/rcm.4511, 2010.

Pintér, K., Balogh, J., and Nagy, Z.: Ecosystem scale carbon dioxide balance of two grasslands in Hungary under dif- ferent weather conditions, Acta Biol. Hung., 61, 130-135, doi:10.1556/ABiol.61.2010.Suppl.13, 2010.

Prudhomme, C., Giuntoli, I., Robinson, E. L., Clark, D. B., Arnell, N. W., Dankers, R., Fekete, B. M., Franssen, W., Gerten, D., Gosling, S. N., Hagemann, S., Hannah, D. M., Kim, H., Masaki, Y., Satoh, Y., Stacke, T., Wada, Y., and Wisser, D.: Hydrological droughts in the 21st century, hotspots and uncertainties from a global multimodel ensemble experiment, P. Natl. Acad. Sci. USA, 111, 3262-3267, doi:10.1073/pnas.1222473110, 2014.

R Core Team: R: A Language and Environment for Statistical Computing, R Foundation for Statistical Computing, Vienna, Austria, 2014.

Reichstein, M., Bahn, M., Ciais, P., Frank, D., Mahecha, M. D., Seneviratne, S. I., Zscheischler, J., Beer, C., Buchmann, N., Frank, D. C., Papale, D., Rammig, A., Smith, P., Thonicke, K., van der Velde, M., Vicca, S., Walz, A., and Wattenbach, M.: Climate extremes and the carbon cycle, Nature, 500, 287-295, doi:10.1038/nature12350, 2013.

Risk, D., Nickerson, N., Creelman, C., McArthur, G., and Owens, J.: Forced Diffusion soil flux: A new technique for continuous monitoring of soil gas efflux, Agr. Forest Meteorol., 151, 16221631, doi:10.1016/j.agrformet.2011.06.020, 2011.

Risk, D., Nickerson, N., Phillips, C. L., Kellman, L., and Moroni, M.: Drought alters respired $\delta^{13} \mathrm{CO}_{2}$ from autotrophic, but not heterotrophic soil respiration, Soil Biol. Biochem., 50, 26-32, doi:10.1016/j.soilbio.2012.01.025, 2012.

Suseela, V. and Dukes, J.: The responses of soil and rhizosphere respiration to simulated climatic changes vary by season, Ecology, 94, 403-413, doi:abs/10.1890/12-0150.1, 2013.

Tennant, D.: A test of a modified line intersect method of estimating root length, J. Ecol., 63, 995-1001, 1975.

van der Heijden, M. G. A., Bardgett, R. D., and van Straalen, N. M.: The unseen majority: soil microbes as drivers of plant diversity and productivity in terrestrial ecosystems, Ecol. Lett., 11, 296310, doi:10.1111/j.1461-0248.2007.01139.x, 2008.

van der Heijden, M. G. A., Martin, F. M., Selosse, M.-A., and Sanders, I. R.: Mycorrhizal ecology and evolution: the past, the present, and the future, New Phytol., 205, 1406-1423, doi:10.1111/nph.13288, 2015.

van der Molen, M. K., Dolman, A. J., Ciais, P., Eglin, T., Gobron, N., Law, B. E., Meir, P., Peters, W., Phillips, O. L., Reichstein, M., Chen, T., Dekker, S. C., Doubková, M., Friedl, M. A., Jung, M., van den Hurk, B. J. J. M., de Jeu, R. A. M., Kruijt, B., Ohta, T., Rebel, K. T., Plummer, S., Seneviratne, S. I., Sitch, S., Teuling, A. J., van der Werf, G. R., and Wang, G.: Drought and ecosystem carbon cycling, Agr. Forest Meteorol., 151, 765-773, doi:10.1016/j.agrformet.2011.01.018, 2011.

Vargas, R., Detto, M., Baldocchi, D. D., and Allen, M. F.: Multiscale analysis of temporal variability of soil $\mathrm{CO}_{2}$ production as influenced by weather and vegetation, Glob. Change Biol., 16, 1589-1605, doi:10.1111/j.1365-2486.2009.02111.x, 2010.

Yang, F. and Zhou, G.: Sensitivity of temperate desert steppe carbon exchange to seasonal droughts and precipitation variations in Inner Mongolia, China, PLoS One, 8, e55418, doi:10.1371/journal.pone.0055418, 2013. 